\title{
Thoughts on Promoting Discipline Construction with Scientific Research in Private Colleges and Universities in the New era
}

\author{
Zhu Guangliang \\ Xi'an Peihua University \\ P. R. China
}

\begin{abstract}
Discipline construction is a fundamental work in the construction and development of colleges and universities, and it is a symbol of the level of operating a school. Strengthening the discipline construction is the basis for private colleges and universities to improve their competitiveness and the quality of personnel training. This paper expounds the position and function of scientific research in discipline construction, analyzes the problems existing in scientific research and discipline construction in private colleges and universities, and gives the method and path for solving the problem of promoting discipline construction by scientific research in private colleges and universities, and provides methods for the construction of high-level disciplines in civil-run universities under the background of the rapid development of new engineering, new medicine, new agriculture and new liberal arts.
\end{abstract}

Keywords—private colleges and universities; scientific research; discipline construction

\section{INTRODUCTION}

After nearly 40 years of development of the private universities in China, the level of school-running schools has been improved year by year, and it has played an important role in higher education. With the decrease of the industrial structure and the number of students, the private colleges and universities pay more attention to the development of the connotation and the construction of quality. The professional construction gradually changes from the focus of the individual professional construction to the construction of the professional group, pays attention to the discipline and subject construction, and some schools will carry out the professional degree post-graduate education as an important sign to improve the school-running level, strengthen the subject construction, and actively carry out the cultivation of the master's degree.As a scientific research to promote the development of discipline construction, more and more private colleges and universities pay attention to it. When the National Natural Science Foundation of China was announced in 2019, a number of private colleges and universities were awarded projects [1]. Under the background of new engineering, new medicine, new agriculture and new liberal arts, private colleges and universities should give full play to their own advantages and keep abreast of regional economic and social development. They should constantly improve the level of scientific research through discipline construction, improve the level of discipline construction through scientific research, and promote the improvement of their own level of running colleges and universities in order to remain invincible in the future competition and build first-class private colleges and universities that can compete with most public colleges and universities.

II. ACCURATELY GRASP THE POSITION AND FUNCTION OF THE SCIENTIFIC RESEARCH IN THE SUBJECT CONSTRUCTION OF THE PRIVATE UNIVERSITY

The purpose of the subject construction is to improve the subject's competitiveness, which is the level of the talent team, the scientific research results and the quality of the personnel training. The builders of the private colleges and universities must recognize the position and function of the scientific research in the subject construction, give full play to the role of scientific research and drive the development of the colleges and universities.

Scientific research is the fundamental measure to strengthen the discipline construction and strengthen the discipline strength of private colleges and universities. Discipline construction is a fundamental problem in the development of colleges and universities. Without a high level of scientific research, there will be no first-class disciplines. The national implementation of "Double first-class" construction [2] is the best explanation that there can be no first-class colleges and universities without first-class disciplines. The main symbol of first-class discipline is the first-class talent team and first-class scientific research results. The strength of private colleges and universities is mainly reflected in the discipline strength, economic strength and human cohesion. Scientific research can enhance the discipline strength, more cohesion of the discipline team, but also bring economic benefits. Private colleges and universities are determined according to their own development. In order to meet the needs of regional economic development and subject construction, we should actively carry out scientific research, expand scientific research channels, and regard scientific research as an important task of school development

Scientific research is the only way to cultivate and exercise the team of subjects. Mei Yiqi, the old president of Tsinghua University, a famous educator, has a famous saying that a great scholar is not a building, but a master. The growth of the master and the growth of the subject team can not be separated from scientific research. Because of the problems of running a school, welfare treatment and social recognition in private colleges and universities, it has always been a difficult point to 
build an excellent teaching staff, which is a deficiency in the development of the school. "unable to attract" can not keep "high-level talents, and the construction of its own team is lack, so it is particularly important to give full play to its own characteristics to cultivate its own academic team. It is urgent to rely on scientific research bases and major scientific research projects to train people through the undertaking department. Research project, effectively organize the academic team, reasonable allocation of human resources, and in the process of engaged in research to cultivate, exercise innovative awareness, management ability, team spirit, improve the level of business, create academic leaders. Scientific research ability is also an important symbol to measure the academic level of the discipline team. Under the existing evaluation mechanism of education and teaching, the output of high quality scientific research and academic achievements is the embodiment of the level of running schools in private colleges and universities. It is necessary for a good scientific research team to apply scientific research academic achievements to teaching, to realize the unity of scientific research, teaching and industry.

Advantages and characteristics are the lifeline of discipline construction, the characteristic is competitiveness, the characteristic is combat effectiveness and vitality, the homogenization of colleges and universities may be eliminated, private colleges and universities to avoid homogenization, in order to work hard on the characteristics, we must make a breakthrough in the combination of scientific research and production and research. In scientific research and discipline construction, on the one hand, private colleges and universities should accurately grasp the needs of national economy, social development, industrial demand, students' future growth and so on; on the other hand, they should find out comparative advantages according to their own conditions, integrate subject resources, highlight their own characteristics, select the correct main direction of attack, and form after a period of cultivation and development. An alternative subject advantage. Therefore, private colleges and universities must choose the right direction, highlight the characteristics, give full play to their advantages, pay attention to the integration of production and education, highlight the practical application, and form the direction of characteristic disciplines in the scientific research work of private colleges and universities.

Scientific research is the main driving force to improve the construction level of subject base. Adhere to the simultaneous development of scientific research base construction and discipline construction. Discipline construction can not be separated from scientific research, scientific research can not be separated from the construction of subject base. At present, private colleges and universities generally lack the construction of subject base, especially the base that can connect with the national strategy is even less, most of them pay attention to the short and smooth project construction, and lack the necessary core competitiveness. To run a high-level university, we must strengthen the infrastructure construction, optimize and improve the scientific research environment and working conditions, strengthen the integration of scientific research and industry and education on the subject base, connect enterprises, keep up with new business type and the new situation in the new era, and revolve around the adjustment of industrial structure. And social development needs, output high-quality applied scientific research results, declare high-level scientific research projects, publish high-quality academic papers, form a good academic atmosphere. In the construction of the base, we should persist in "doing something and not doing something", should not grasp the beard and eyebrows, form the discipline foundation well, form the superior discipline, build the demonstration discipline base, make its scientific research condition reach the first-class level in the region, attract and train the first-class talents, take the high level project, produce the high quality achievement, form the good scientific research environment of the talent, the project and the base organic allocation.

Scientific research achievements are an important support for private colleges and universities to apply for master's authorization. The state has opened the door to all private universities to carry out graduate education. Five private colleges and universities have carried out graduate education according to the "serving the National Special needs Talent training Project" [3]. One of the private colleges and universities has obtained master's degree authorization unit in 2018 [4], which has ignited the enthusiasm of private colleges and universities to apply for master's degree authorization. At present, undergraduate education in our country is gradually moving towards popular education, but graduate education is still elite education and the way to cultivate high-level talents. Private colleges and universities have a long way to go to carry out graduate education. The State is awarded a master's degree. In order to carry out graduate education and obtain the authorization of master's degree, private colleges and universities must closely combine scientific research and subject construction, obtain sufficient scientific research funds, produce high-quality scientific research results, refine the direction of characteristic disciplines, and lay a solid discipline foundation for applying for master's degree authorization.

\section{THE MAIN PROBLEMS EXISTING IN THE SCIENTIFIC RESEARCH AND SUBJECT CONSTRUCTION OF PRIVATE COLLEGES AND UNIVERSITIES AT PRESENT}

As early as 2002, Professor Liu Xianjun published a paper entitled "there is no first-class university without first-class disciplines" in Qiushi[5]. The necessary conditions for building first-class disciplines to become first-class universities have been gradually recognized by the society. The state actively promotes the construction of first-class universities and first-class disciplines. In 2017, it announced the list of "double first-class construction". Building double first-class and studying from double first-class colleges and universities has become the direction of the development of colleges and universities. Private colleges and universities are still far from the double first-class standards, especially in discipline construction and scientific research.

The consciousness of discipline construction in private colleges and universities is lack, and there is no advantage of subject group. Due to the influence of the employment market and the pursuit of the efficiency of running a school, private colleges and universities regard the subject major which can attract the source of students as the development direction of 
the school, which leads to the instability of the subject specialty, resulting in the insufficient precipitation of the subject and the lack of outstanding dominant disciplines. With the emergence of new engineering, new medicine, new agriculture and new liberal arts, the interdisciplinary integration is more prominent. It is not only necessary for the same category of disciplines to break down obstacles, communicate and combine, but also for different types of disciplines to cross, infiltrate and integrate, in order to derive new branches of disciplines at their joint point. In order to promote the development of the subject. Private colleges and universities should set up the consciousness of strengthening the discipline, according to the law of the development of the discipline itself and the specific situation of the discipline, on the basis of building a single discipline, strengthen the communication and cooperation among disciplines, and form the group advantage of the subject. Only in this way can we quickly improve the comprehensive strength of running a school in private colleges and universities.

The strength of teachers in private colleges and universities is weak and lack of subject leaders. The key and core of discipline construction is the construction of team. Without a first-class team, there is no first-class discipline, and the subject leader is the "leader" of the academic team, which is the key. Most of the teachers who can bear the subject leaders in private colleges and universities are retired teachers from public colleges and universities, and have rich experience in research and team building, but it is determined that the original teams are basically retained in the original units, and it is very difficult for them to set up teams in private colleges and universities, resulting in temporary patchwork of subject teams and no stable echelon. Private Colleges and Universities must add Big investment, build strong teaching staff, especially to train young and middle-aged as the backbone of the subject echelon, train their own subject leaders.

The research direction of private colleges and universities is unstable, there are some problems, such as outdated direction, homogenization and so on. The direction of subject research is the leader of the discipline, and the establishment of the research direction is a very important link in the discipline construction, which will restrict or drive the development of other tasks of the discipline construction. In the discipline construction of private colleges and universities, the problems of subject research direction are mainly reflected in the aspects of outdated direction, homogenization, non-focus, disconnection with practical application and so on. The research direction is old, which is out of touch with the present situation and trend of international and domestic research in this subject field, and lacks new ideas and frontiers; the content of the subject research direction is homogeneous with other local colleges and universities, and its own characteristics are not distinct. There is a lack of characteristics and advantages; the research direction is of great randomness, rapid change, lack of relative stability, and it is difficult to form the advantage of this research direction; the research of the team personnel is not focused, and the research power is dispersed.

\section{STRATEGIES FOR PROMOTING GOOD INTERACTION BETWEEN SCIENTIFIC RESEARCH AND DISCIPLINE CONSTRUCTION IN PRIVATE COLLEGES}

The combination of scientific research and subject construction can promote the development of both, and it is an important problem to be solved in the high-level university. The relationship between the scientific research and the subject construction is mutually reinforcing, the scientific research is the foundation of the subject construction, and a high level of scientific research will make the overall strength of the subject develop continuously. To give full play to the leading role of scientific research in the subject construction, it is necessary to pay attention to the following aspects.

Private colleges and universities must establish the scientific research innovation target system as the primary task, in order to condensed the subject direction. This is determined by the nature of scientific research and innovation. The value of science is to discover the objective law that does not take people's will as the transfer and can not be changed by human beings. It is not only the goal pursued by the scientific research institute, but also the driving force of scientific research. Without innovation goals, or innovation goals are not clear, there can be no clear subject direction. Private colleges and universities should combine the needs of regional economic development and personnel training, through the key scientific research projects, form a characteristic research direction suitable for the national strategy and regional economy, and apply for master's degree authorization for the school.

Private colleges and universities must combine with the transformation of subject achievements and social service in order to give full play to the benefits of disciplines. Private colleges and universities should make full use of the characteristics of applied running schools and close to the market to speed up the transformation of scientific research achievements. In the process of identifying and popularizing scientific research achievements, experts from enterprises and institutions of higher learning should be widely invited to participate in order to improve the popularity and influence of the achievements. It is necessary to do a good job in publicizing the achievements, actively participating in various types of national scientific research results trading fairs, entering the scientific research results databases in various localities, and laying a good foundation for the transformation of scientific research achievements into economic benefits. In scientific research, we should insist on grasping with both hands, both hands should be hard, and the other hand should grasp the vertical subject. At the same time, scientific research should be combined with horizontal topics, promote each other, advocate vertical and horizontal combination, promote vertical and horizontal scientific research, promote scientific research into high and new technology, apply, develop, and speed up the transformation of scientific and technological achievements into productive forces in order to promote the extension of scientific research to high and new technology, to the application, to the development and expansion, and to the transformation of scientific and technological achievements to productive forces. 
Private colleges and universities must be combined with the construction of subject base in order to consolidate the subject foundation. The subject base not only includes all kinds of laboratories, books and information materials and other hardware equipment, but also includes scientific research service system, scientific research atmosphere and other soft environment. It is necessary to integrate scientific research forces, further strengthen the investment in key laboratories and the construction of infrastructure, and apply artificial intelligence, big data, block chain and other technologies to laboratory construction, in order to improve scientific research conditions and enhance competitive strength, implement the management mode of open use and resource sharing, adjust the personnel structure and layout of existing laboratories, open up research directions, and enhance research strength; at the same time, we should pay attention to the soft environment of disciplines. In order to build and continuously develop a scientific research atmosphere conducive to innovation, this atmosphere should be to encourage innovation and creation, encourage top-notch innovation, encourage competition and cooperation, encourage talent to produce results, form and improve the academic environment conducive to innovation, encourage the vast number of scientific research personnel to carry out academic contending and exploration, promote academic exchanges, further form an environment that respects knowledge, respect talents, and improve the mechanism of rewards and punishments. From all aspects of the establishment of talent, results, conducive to innovative soil and environment. In addition, it is necessary to form a mechanism for hardware construction to promote software development, such as guiding the direction of scientific research through investment in funds and guiding the energy investment of scientific and technological personnel. To promote the construction of public service platform, to promote the sharing of resources, to unite the team, to promote the formation of the consortium through the establishment of large projects, to promote the direction of scientific research and the stability of the research echelon, and so on, and finally to form a new mechanism for the mutual promotion and development of software and hardware, so as to lay a solid foundation for improving the level of discipline construction.

Private colleges and universities must combine scientific research with the construction of talent team in order to build subject team. The orientation of private colleges and universities is basically local applied undergraduate colleges and universities. Scientific research must be closely combined with the integration of industry and education, must adapt to national strategy and regional social development, build disciplines with distinctive characteristics, and establish a scientific research team with reasonable structure, outstanding innovation ability and strong practical application ability around the construction of disciplines and specialties. This team should have three qualities: first, the compound knowledge structure, the technology-intensive, complex elements and highly comprehensive elements involved in modern industry, and to solve the major problems in the frontier field of technology, it is necessary to solve the major problems in the frontier field of technology. We must take the road of joint tackling key problems, and only with compound knowledge structure can we meet the requirements of joint tackling key problems. Second, applied innovation ability, scientific research is the best innovation activity, a teacher with continuous innovation ability, it is possible to make teaching full of vitality, in order to meet the requirements of subject construction. Third, the spirit of cooperation and the development of modern science make the development of any subject more dependent on the cross-integration and comprehensive integration of different disciplines, and it is impossible to create great scientific research achievements by individual struggle alone, which requires scientific researchers to have a broad mind and cooperative spirit. Therefore, it is necessary to improve the knowledge structure of scientific researchers. In the research practice, we should vigorously cultivate the spirit of cooperation and form a subject team with strong innovation ability.

\section{CONCLUSION}

With the development of society and the progress of science and technology, private colleges and universities have entered a new era and opened a new situation of running quality schools. The coordinated development of scientific research and subject construction has become an important topic in the research of private colleges and universities. Private colleges and universities should closely follow the national strategy and regional economic development, unify ideas, condense consensus, clarify the objectives of discipline construction, accurately grasp the relationship between scientific research and discipline construction, give full play to the role of scientific research in promoting discipline construction, analyze and find out their own problems in scientific research and discipline construction, implement the strategy of scientific research to promote discipline construction, highlight student-centered, and form subject characteristics. To improve the level of running a school in an all-round way, we can compete in the competition.

\section{REFERENCES}

[1] Http://www.nsfc.gov.cn/publish/portal0/tab434/info76217.htm

[2] Http://www.moe.gov.cn/srcsite/A22/moe_843/201709/t20170921_3149 42.html

[3] Http://www.moe.gov.cn/srcsite/A22/s7065/201110/t20111017_138061. html

[4] Http://Www.Moe.Gov.Cn/Srcsite/A22/Yjss_Xwgl/Moe_818/201805/T2 0180509_335457.Html

[5] Liu Xianjun. Without a first-class subject, there is no first-class university [J]. Qiushi.2002(3):54-55

[6] You Hai. On several Relations of discipline Construction in Colleges and Universities[J].Academic Degrees \& Graduate Education. 2004(12):1-5.

[7] Zeng Linfeng. Improve the level of scientific research and promote the construction of disciplines [J].Journal of GuangXi Teachers Education University. 2004(2):84-88. 